Abstracta Iranica Abstanica

Revue bibliographique pour le domaine irano-aryen

Volume 24 | 2003

Comptes rendus des publications de 2001

\title{
Pātoq. Tehrān, Nāmjūfard, 1380/2001, 247 p. [Club, repère, carré, quartier...]
}

\section{Christophe Balaÿ}

\section{Q OpenEdition \\ 1 Journals}

Édition électronique

URL : http://journals.openedition.org/abstractairanica/35021

ISSN : 1961-960X

\section{Éditeur :}

CNRS (UMR 7528 Mondes iraniens et indiens), Éditions de l'IFRI

\section{Édition imprimée}

Date de publication : 15 mai 2003

ISSN : 0240-8910

\section{Référence électronique}

Christophe Balaÿ, « Pātoq. Tehrān, Nāmjūfard, 1380/2001, 247 p. [Club, repère, carré, quartier...] »,

Abstracta Iranica [En ligne], Volume 24 | 2003, document 381, mis en ligne le 05 janvier 2010, consulté le 25 septembre 2020. URL : http://journals.openedition.org/abstractairanica/35021

Ce document a été généré automatiquement le 25 septembre 2020.

Tous droits réservés 


\section{Pātoq. Tehrān, Nāmjūfard, 1380/2001, 247 p. [Club, repère, carré, quartier...]}

\section{Christophe Balaÿ}

1 Recueil d'entretiens conduits par un groupe d'étudiants avec des artistes et gens de cinéma et de théâtre sur environ deux années consécutives. On trouvera réunis des acteurs, des metteurs en scène, des écrivains, des scénaristes, des jeunes, des anciens... $\mathrm{Au}$ fil des rencontres c'est à la fois un art en plein épanouissement mais aussi un nouveau type de société, de nouveaux regards, des modes de vie différents qui sont décrits et nous donnent à lire et relire la société iranienne post-révolutionnaire.

INDEX

Thèmes : 17.2. Arts du spectacle

\section{AUTEURS}

\section{CHRISTOPHE BALAŸ}

IFRI - INaLCO - Téhéran - Paris 